\title{
CORRELATION OF LABORATORY EXPERTS' PERFORMANCES IN PRIMARY HEALTH CARE (PUSKESMAS) AND PATIENCE PERCEPTION
}

\author{
Hilda Meriyandah Agil ${ }^{1}$, Rina Veronica ${ }^{1}$, Tjipto Rini ${ }^{2}$, \\ ${ }^{1}$ Departemen Kesehatan Masyarakat, Institut Kesehatan Indonesia \\ ${ }^{2}$ Prodi Kesehatan Masyarakat, Politeknik Kesehatan Kementerian Kesehatan Jakarta II, Jakarta, \\ Indonesia \\ hilda.meriyandah@gmail.com
}

\begin{abstract}
Health laboratory services are an integral part of health services to the community and expected to provide accurate information in all stages: pre-analytic, analytic and post-analytic. This study aimed to determine the relationship between laboratory experts' performances in Primary Health Care (Puskesmas) against community perceptions conducted in 24 Puskesmas in Surabaya with a-sample of 30 laboratory experts and 30 communities. This was a multivariate analysis research and data was obtained from the questionnaires given to the respondents and then performed data analysis using Pearson correlation. The results indicated there was a significant relationship between the performance of laboratory experts with the perception of the community $(\rho=0.001)$. There is a relationship between the pre-analytic stage performance $(\rho=0.002)$, the analytic stage $(\rho=0.004)$ and post-analytic $(\rho=0.007)$. Based on the performance appraisal of laboratory personnel in the Puskesmas including significant pre-analytic, analytic and post-analytic activities on public perceptions there was a significant relationship, and the most significant relationship was found at the pre-analytic stage.
\end{abstract}

Keywords: Health service, laboratory experts' performances, perception.

\begin{abstract}
ABSTRAK
Pelayanan laboratorium kesehatan merupakan bagian yang tidak terpisahkan dari pelayanan kesehatan kepada masyarakat dan diharapkan dapat memberikan informasi yang akurat dalam setiap tahapnya: pra-analitik, analitik, dan pasca analitik. Penelitian ini bertujuan untuk mengetahui hubungan antara kinerja laboratorium di Puskesmas terhadap persepsi masyarakat yang dilakukan di 24 Puskesmas di Surabaya dengan sampel sebanyak 30 tenaga laboratorium dan 30 masyarakat. Bagian ini menjelaskan secara jelas dan singkat tentang langkah-langkah penelitian yang dilakukan. Hasil penelitian ini menunjukkan bahwa terdapat hubungan yang signifikan antara kinerja tenaga laboratorium di Puskesmas dengan persepsi masyarakat dengan $\rho=0,001$. Terdapat hubungan antara kinerja tahap pra analitik $(\rho=0,002)$, tahap analitik $(\rho=0,004)$ dan pasca analitik $(\rho=0,007)$. Terdapat hubungan yang signifikan antara kinerja petugas laboratorium di Puskesmas dengan persepsi masyarakat, dan yang paling signifikan berada di tahap pra-analitik.
\end{abstract}

Kata Kunci: Kinerja laboratorium, Pelayanan kesehatan, Persepsi 


\section{INTRODUCTION}

Service is the key to success in a business, especially for service orientedbusiness. It contributes bigger impact when there is competition in the effort to seize the market or subscription. This condition requires the organization or company to compete in the implementation of services, through various ways, techniques and methods that can attract more people who use services or products. Competition in the community is not only in terms of quality and quantity, but also in terms of services (Moenir, 2006).

One type of service provided by the government is services in the health sector, especially public health services, which are part of health services aimed to improve health and prevent diseases with the main target is people in community (Asmawati, 2011). Health development has a vision of "Indonesia or healthy people" - Indonesia atau masyarakat sehat, one of the program is implemented through health services by Primary Health Care Centre and Hospitals (Kepmenkes, 2004).

In order to provide a comprehensive health care services to all communities in its work area, the Puskesmas carries out several basic services which include maternal and child health programs, family planning, eradicating infectious diseases, improving nutrition, environmental health, medicine, health education community, laboratory, school health, public health care, mental health, and dental (Muninjaya, 2004).

Health laboratory services are an integral part of health services to the community. The health laboratory as a medical support service unit is expected to provide accurate and details information about the laboratory aspects of specimens or samples which tested in the laboratory. Indonesian health laboratory services are currently held by various levels of service, including Puskesmas laboratories, government and private hospital laboratories, Health Laboratory Centers and private health laboratories (Depkes, 2008).

The number of primary health care facilities such as laboratories should be increased as the Health Ministry Regulations No. 752014 (Depkes, 2014). The competing laboratories in their implementation prioritize the quality of services and facilities, then impact to service utilization. Good service satisfies service users (Rini, 2011).
In this globalization era, the standardization of laboratory service quality is necessary. Legislation has begun to be directed at the readiness of the entire health profession in welcoming the globalization. Laboratory experts which consisted of health analysts and laboratory practitioners must constantly develop themselves in providing the needs of community for quality assurance on lab's results and the demands for excellent service (Kepmenkes, 2007).

The community requires the quality of laboratory tests to be continuously improved in line with the advancement of science, technology, and the development of disease. The quality of service can be demonstrated by adding existing facilities, increasing the number of inspection items, sources of information such as diagnostic explanations, smiles, and friendly attitudes, technical skills in managing clinical laboratories, interpersonal relationships such as privatization, behavior of respectful and responsive laboratory personnel, confidentiality, short waiting time, and sufficient time provided (Rini, 2011). Besides, the quality of laboratory services shows more to aspects of laboratory examination starting from pre-analytic, analytic and post-analytic, while for service users are accuracy and time (Depkes, 2008).

The quality service defined as providing satisfaction to service users. Satisfaction or dissatisfaction is users' appraisement after comparing their perception of performance with its expectations. Customer expectations are formed and based on several factors, including past experience, friend's opinions, and company information, promises, and competitors (Rini, 2011).

Based on a study held by Setia, et al (2017) in Kota Banjarbaru found there was significant relation between the quality of laboratory services to community satisfaction. Therefore, inadequate facilities and infrastructure of Puskesmas, less skilled health workers, and length of examination were determining factors to the community's preference to get examinations in hospital laboratories and other private laboratories. However, providing the quality of health services in Puskesmas is government's responsibility and it is really necessary to improve laboratory facility in Puskesmas. Since the utilization of scientifically valid methods, laboratories steps and results, to 
generate the data and develop a precise diagnosis and intervention is the essence of public health (Bloland et al., 2012;Setia et al., 2017)

Based on those descriptions, it was necessary to conduct a research about "the relationship between laboratory experts performances in primary health care (Puskesmas) and patience perception".

\section{METHOD}

This study employed multivariate analysis methods, because a lot of emphasis was given to the measurement of research variables with data analysis numbers and carried out with statistical procedures.

The current study was conducted in 24 Puskesmas located in Surabaya City and carried out in June 2013. The samples criteria for laboratory experts were (1) All health laboratory staff working in Puskesmas of Surabaya City, (2) have been working for 3 years, and (3) consent to join the study. Besides, we recruited 30 participants as well from the community with criteria (1) age between 18 to 60 years old; (2) inexperienced the laboratory services in Puskesmas; and (3) consent to join the study.

The numbers of samples were referred from Bailey (1978) stated the minimum participants number is 30 considered the cost effectiveness of research outcome (Cohen et.al., 2000; Gates, D., 2006). The samples recruited by a non-probability way with purposive sampling technique. Sampling is purposively based on certain criteria made by the researcher, that is, every subject that meets the above mentioned criteria is included in the research sample until the required amount is fulfilled.

In the preparation stage, researchers developed a proposal and submit documents to obtain research permit from the Health Ministry of Health Polytechnic Surabaya. In addition, researchers also prepared the questionnaire by compiling a list of questions.

The implementation stage included the recruitment process, so the respondents who were willing to be interviewed, by decided the time and place, then the researcher conducted an interview by visiting the respondents. Researchers documented the results of interviews to avoid any missing data.

The data obtained from the results of this study were primary data which collected originally by the researchers. Collecting data in this study done by using research instruments created by researchers. The questionnaire used Likert Scale which the highest score was 5 (strongly agree) and 1 for the lowest score (strongly disagree). Prior to the data collecting process, a validity test was conducted to determine the extent to which an instrument can measure what is measured (leading to data accuracy) and reliability testing to determine whether the instrument can provide consistent measurement results. From the prior process, questionnaire for laboratory experts resulted the value of cronbach alpha and $\mathrm{r}$ values were 0.755 and 0.419 respectively. While the questionnaire for communities perception obtained the value of cronbach alpha and $r$ values were 0.741 and 0.506 respectively Finally, the real data collection was done and processed using statistical analysis of Pearson correlation using SPPS to see the effect between the performance of laboratory personnel and public perception.

\section{RESULTS}

\section{General Findings of Laboratory Performances}

Laboratory performances includes preanalytic, analytical and post-analytic stages.

Table 1. Data distribution of laboratory performances

\begin{tabular}{|l|c|c|c|}
\hline \multirow{2}{*}{\multicolumn{1}{c|}{ Variable }} & \multicolumn{3}{|c|}{ Value } \\
\cline { 2 - 4 } & Strongly agreed & Agreed & Less agreed \\
\hline Pra-analytic & $106(71 \%)$ & $41(27 \%)$ & $3 \quad(2 \%)$ \\
\hline Analytic & $115(77 \%)$ & $35(23 \%)$ & $0 \quad(0 \%)$ \\
\hline Post-analytic & $88(59 \%)$ & $48(32 \%)$ & $3 \quad(2 \%)$ \\
\hline
\end{tabular}

Most of laboratory experts evaluated their performances were good in all stages. The analytic stage obtained the highest value, followed by pre-analytic and analytic stages. It might be caused, the laboratory experts considered their main job is 
collecting specimen, and they evaluated their skill in this term was good.

\section{General Findings of Community Perception}

As well as the finding of laboratory performances, the community perception has three stages.

Table 2. Data distribution of community perception

\begin{tabular}{|l|c|c|c|}
\hline \multirow{2}{*}{ Variable } & \multicolumn{3}{|c|}{ Value } \\
\cline { 2 - 4 } & Strongly agreed & Agreed & Less agreed \\
\hline \multirow{2}{*}{ Pre-analytic } & 72 & 72 & $6 \quad(4 \%)$ \\
& $(48 \%)$ & $(48 \%)$ & $8 \quad(5 \%)$ \\
\hline Analytic & $69(46 \%)$ & $73(49 \%)$ & $1 \quad(0.5 \%)$ \\
\hline Post-analytic & $61(40.5 \%)$ & $73(49 \%)$ & \\
\hline
\end{tabular}

The data above represents the community perception of laboratory performances were likely good in all stages. Different with laboratory experts' evaluation, the community gave the highest score (strongly agreed) in the pre-analytic stage, and followed by analytic stage and post-analytic stage respectively. They might found the laboratory experts' performances were impressed them at the beginning. Since the pre-analytic is discussed about laboratory experts' responsibility, friendly, and provided information before the test.

\section{Significant Relationship Laboratory Performances and Community Perception in Each Stage}

From table 1 it is known that there was a significant relationship between laboratory performance and public perception with $\rho=$ 0.001 . Therefore, it concluded that there was a relationship between the performance of laboratory personnel in the Puskesmas and the community perception.

Table 3. Relationship between laboratory experts' performances and community perceptions

\begin{tabular}{|l|c|}
\hline \multicolumn{1}{|c|}{ Variable } & Laboratory experts' performances \\
\hline Coef. correlation & 0.558 \\
\hline Significant $(\rho)$ & 0.001 \\
\hline
\end{tabular}

Table 4. Relationship between laboratory experts' performances in pre-analytic, analytic, and postanalytic stages

\begin{tabular}{|l|c|c|}
\hline \multicolumn{1}{|c|}{ Variable } & R & Sig \\
\hline Pra-analytic & 0.543 & 0.002 \\
\hline Analytic & 0.505 & 0.004 \\
\hline Post-analytic & 0.484 & 0.007 \\
\hline
\end{tabular}

Table 2. shows that there is a relationship between the pre-analytic, analytic and post-analytic stages. Among the three phases of this laboratory which provides a significant relationship with community perception is the pre-analytic stage $(\rho=0.002)$, besides the analytic stage also relates to the perception of society $(\rho=0.004)$ and post analytic $(\rho=0.007)$.

\section{DISCUSSION}

The findings pointed out the availability of laboratory services and skilled laboratory experts were important to improve community perception. It is in line with Lubis (2018) research that the perception of service quality has a positive effect on customer satisfaction, namely the availability of 
sufficient number of medical personnel and fulfilling the qualifications of workers according to the types of laboratory services available. Some efforts in improving the perception of service quality are related to medical equipment facilities and other facilities and infrastructure that are used objectively, systematically and continue to have a good impact on the creation of customer satisfaction.

The current findings also emphasized the previous study (Himawan, 2016) which showed the results that the performance of puskesmas employees was not in accordance with the standards applied and there were stillundisciplined individuals about the time and building facilities that stood in flood-prone areas and supporting and inhibiting factors. Performance of employee health services to the community.

Based on research conducted in June 2013, there was a significant relationship between the performance of laboratory personnel and the public perception. This can be seen from the results of Pearson correlation test with a value of $\rho=0.001$. Separately both in the pre-analytic, analytic and post-analytic stages there is also a significant relationship to public perception.

When analyzed separately between pre-analytic, analytic and post-analytic stages, different significance values were obtained. The pre-analytic stage has a more significant significance value $(\rho=0.002)$ than the analytic or post-analytic stage. The analytical stage has a significance value $\rho=0.004$ while the post analytic stage with a significance value $\rho=$ 0.007 . The pre-analytic stage in this study focused more on the services provided including communication with patients, providing clear information about laboratory examinations, attitudes given by the officer in this case hospitality, responsiveness given by officers in responding to patient complaints.

It turned out that the respondents in this study, still thought that the services of health laboratory personnel with good communication, had a better impact than theexamination process carried out. This is in line with the opinion of Rangkuti, 2006 which states that perception is a process in which individuals choose, organize, and interpret stimuli received through their senses into a meaning.
In Rangkuti (2006) research also discussed the analysis of the quality of drinking water service performance stating that the quality determinant variable is the ability of officers to carry out services, speed and responsiveness of officers in providing services, security and courtesy of officers and trustworthiness, caring officers in providing services, and officer appearance, physical, and service office facilities. One of the determinants of quality in service is the friendliness and courtesy of complaints officers in providing services, attitudes of officers at payment counters, attitudes of technical officers to customers in carrying out their duties, and cleanliness and neatness of officers' clothes.

The same thing was disclosed by Hasbi (2012) in his research regarding the analysis of the relationship of patient perceptions of service quality with the reuse of outpatient care at Poncol Health Center in Semarang City which stated that the community's interest in utilizing outpatient services at Poncol Health Center in Semarang was influenced by several factors including patient perception of service quality outpatient.

Likewise with Aryastami $\mathrm{K}$ and Hendarwan's (2006) research which explains measuring community perceptions of the responsiveness of the health service system can illustrate the success of the puskesmas in an effort to increase access and reach of the public to public services.

\section{CONCLUSION}

From some of the discussions described in this study, it can be concluded that there were significant relationship between laboratory experts' performances in all and each stage, pre-analytic, analytic and postanalytic, with community perception. The most significant relationship was the relationship between the performances of laboratory personnel in the pre-analytic stage on public perception.

\section{RECOMMENDATION}

The further study needs to be more objective in evaluating the influence factors to laboratory experts' performances. Besides, it is really necessary to Puskesmas staff to do socialization about available services in Puskesmas. Last, the quality communication is 
important for all laboratory experts to improve Puskesmas quality services.

\section{REFERENCES}

Aryastami K and Hendarwan, H. 2006. Persepsi Masyarakat Terhadap Ketanggapan Pelayanan Kesehatan di Puskesmas Kabupaten Ogan Komering Ilir Sumatera Selatan. Buletin Penelitian Kesehatan, 11(2), pp. 127-133.

Asmawati. 2011. Persepsi Pasien Rawat Jalan terhadap Kualitas Pelayanan Laboratorium di Rumah Sakit Umum Daerah Bima Nusa Tenggara Barat. Politeknik Kesehatan Jogjakarta.

Bloland, P. et al. 2012. The role of public health institutions in global health system strengthening efforts: The US CDC's perspective. PLoS Medicine, 9(4).

doi:

10.1371/journal.pmed.1001199.

Depkes. 2008. Pedoman Praktik Laboratorium

Kesehatan Yang Benar (Good Laboratory Practice). Direktorat Jenderal Bina Pelayanan dan Penunjang Medik.

Depkes. 2014. Peraturan Menteri Kesehatan Republik Indonesia tentang Pusat Kesehatan Masyarakat.

Hasbi, F. H. 2012. Analisis Hubungan Persepsi Pasien Tentang Mutu Pelayanan Dengan Pemanfaatan Ulang Pelayanan Rawat Jalan Puskesmas Poncol Kota Semarang Tahun 2012. Jurnal Kesehatan Masyarakat Universitas Diponegoro, 1(2), pp. 37-47.

Himawan, F. 2016. Kinerja pegawai dalam pelayanan Kesehatan Masyarakat di Puskesmas Sempaja Kota Samarinda. Ejournal Ilmu Pemerintahan, 4(3). Diakses dari: https://ejournal.ip.fisipunmul.ac.id/site/?p=2111.

Kepmenkes. 2004. Nomor: 128/Menkes/SK/II/ 2004 tentang Kebijakan Dasar Pusat Kesehatan Masyarakat.

$\begin{array}{ccc}\text { Kepmenkes. } & \text { 2007. } & \text { Nomor: } \\ \text { 370/Menkes/SK/III/2007 } & \text { tentang } \\ \text { Standar Profesi Ahli } & \text { Teknologi } \\ \text { Laboratorium } & \text { Kesehatan } & \text { Republik } \\ \text { Indonesia. } & & \end{array}$

Lubis, K. S. 2018. Hubungan Persepsi Mutu Pelayanan dengan Kepuasan Pelanggan. Jurnal daya saing, 4(1).
Moenir. 2006. Manajemen Pelayanan Umum di Indonesia. Edisi I. Jakarta: Bumi Aksara.

Muninjaya, A. A. G. 2004. Manajemen Kesehatan. Edisi 2. Jakarta: Buku Kedokteran EGC.

Rangkuti, F. 2006. Teknik Mengukur dan Strategi Meningkatkan Kepuasan Pelanggan plus Analisis Kasus PLN-JP. Jakarta: Gramedia Pustaka Utama.

Rini, T. 2011. Pengaruh Awarenes Management dan Organizational Commitment terhadap Responsive Culture serta Implikasinya pada Kompetensi Tenaga Laboratorium Kesehatan Pemerintah maupun Swasta. Disertasi, Universitas Airlangga Surabaya.

Setia, L., Muhyi, R. and Husaini, H. 2017. Pengaruh Mutu Pelayanan Terhadap Persepsi Kepuasan Pasien Di Laboratorium Puskesmas Kota Banjarbaru Tahun 2016. Jurnal Berkala Kesehatan, 3(1), pp. 9-17. doi: 10.20527/jbk.v3i1.4847. 